\section{FedUni ResearchOnline}

\section{https://researchonline.federation.edu.au}

Copyright Notice

This is the published version of:

Robinson,J., Smyth, J., Down, B., \& Mclnerney, P. (2012). Pushed out, shut out: Addressing unjust geographies of schooling and work. International Journal of Environmental Research and Public Health, 9 (2), 7-24. https://doi.org/10.18546/IJSD.09.2.02

Available online at: https://doi.org/10.18546/IJSD.09.2.02

(c) 2012 by the authors. This article is an open access article distributed under the terms and conditions of the Creative Commons Attribution (CC BY) license

(http://creativecommons.org/licenses/by/4.0/) which permits unrestricted use, distribution, and reproduction in any medium, provided you give appropriate credit to the original author(s) and the source, provide a link to the Creative Commons license, and indicate if changes were made. 


\title{
Pushed out, shut out: Addressing unjust geographies of schooling and work
}

\author{
Janean Robinson* \\ Murdoch University \\ John Smyth \\ University of Ballarat \\ Barry Down \\ Murdoch University \\ Peter Mclnerney \\ University of Ballarat
}

In neo-liberal times educational policy and practice is being realigned more closely to the shifting imperatives of the market with damaging effects on the lives of young people. Whilst the rhetoric suggests that schools are safe, welcoming and caring environments for the benefit of all, the veracity is very different for significant numbers of marginalised students who face fragile, uncertain and unpredictable futures. This paper draws on a number of research projects in Australia to investigate the lived reality of students who are struggling to make sense of school and their transition to 'getting a job'. The research is neither impartial nor neutral. It draws on the tradition of critical policy ethnography to identify, describe and map the kinds of conditions that both constrain and enable the aspirations, dreams and hopes of young people for productive and rewarding lives. The intent is to unsettle commonsense and deficit understandings of school life that serve to oppress and marginalise the least advantaged students.

\section{Introduction}

Our intent in this paper is to make sense of how young people (especially among young people from backgrounds deemed to be 'disadvantaged') connect to and make sense of schools, or concomitantly, how they are exiled, extirpated or alienated from schooling, and how their experience of school impacts on the process of 'getting a job'. In this way we can not only visualise, but also understand schools as places in which social relations are shaped, contested, and animated and social injustices enacted, sustained and maintained because we can view them through how young people themselves are organised and how they live and experience the dynamics of schooling, work and disadvantage in the Australian context. Their stories provide us with 'a powerful referent' (Giroux, 2011, p.140) with which to interrogate 'the heartbeat of politics' (Giroux, 2011, p.140) and rich counter-narratives to the deficit thinking that informs official policies and practices. Significantly, these personal narratives offer important clues about the kinds of pedagogical, cultural, economic and organisational conditions that work best for them.

* Corresponding author: J.Robinson@ @urdoch.edu.au 


\section{Context and methodology}

In this paper we draw from four related studies that share a common focus around the lives and experiences of the increasingly most marginalised and alienated students - those often labelled as 'disadvantaged', 'at risk', 'under performers', 'trouble makers' or failures' - and who in many instances are evicted from school or choose to leave of their own volition. Firstly, we draw from insights derived from a doctoral study on behaviour management and student voice (Robinson, 2011). Secondly, we examine aspects of student engagement (Smyth and McInerney, 2010-2012), school retention (Smyth and Down, 2005-2007) and vocationalism in contexts of socioeconomic disadvantage (Down and Smyth, 2010-2013). This second cluster of three studies are particularly relevant for regional universities in Australia as they strive to improve higher education participation rates, especially those students from low socioeconomic backgrounds who are poorly represented in Australian higher education (James, 2002).

Research into these issues was undertaken in a cluster of government secondary schools in Bountiful Bay (pseudonym) Western Australia, and alternative learning (second chance) centres in the Wirra Wagga (pseudonym) region of Victoria. Though somewhat disparate in terms of their geographical location, these sites shared some common features. First, notwithstanding the supposed benefits of a mineral resource boom, communities in these areas have been severely impacted by globalization and neoliberal policies that have led to high levels of unemployment, especially amongst young people, low levels of weekly earnings and increasing welfare dependency which have exacerbated the extent of socioeconomic disadvantage. Second, high school completion rates in these (and other) rural and regional communities across Australia are well below the national average of 70 per cent (Foundation for Young Australians, 2010; WA Department of Education, 2010) - a situation which has serious implications for Australia's economic and social development not to mention young people themselves who are unable to obtain a Youth Allowance unless they participate in either full-time (at least 25 hours a week) education, training or employment or a combination until age 17. It is also important to note that in most Australian States and Territories, young people are legally obliged to attend school until they are 17 years of age.

The four projects involved a total of 153 students of both genders whose ages ranged between 14 and 23 years of age either attending or in transition from secondary high school to work. We position each of these studies as deploying a broadly critical ethnographic approach based on the view that research has 'an ethical responsibility to address processes of unfairness or injustice within a particular lived domain' (Madison, 2005, p.5). As Down and Smyth (2010) explain elsewhere, this kind of theoretical and political orientation is 'explicit about our non-detached perspective, our concern to find out from young people about how they believe power works, and our belief in the need for informants to have considerable scope in the 
way they tell us their stories and how they make sense of their lives - all of which places this study in the socially critical domain' (p.8). Listening to students' stories in these ways opens up for investigation a richer set of sociological and political explanations behind the apparent failure of many young people to succeed in school whilst also exposing the myths implicit in 'deficit thinking' about young people (Valencia, 2010).

Specifically, the research utilised the techniques of embedded interviews or purposeful conversations (Burgess, 1988), dialectical theory building (Lather, 1986), and portraiture (Lawrence-Lightfoot and Davis, 1997). All interviews were conducted by the researchers with the participants either one-on-one or in the case of Robinson (2011) in pairs or groups of 4, choosing themselves to be interviewed together with peers. All interviews, semi-structured and dialogic in nature, were held at least twice and each lasted approximately 30-40 minutes. Due to the conversational style of interviewing the ethical problem of the interviews being controlled by the researcher were minimised (Nespor, 1997, p.232). The intent was to allow participants to provide accounts of their own experience in a more informal manner (Clandinin and Connelly, 1994, p.420). A follow up interview provided an opportunity to deepen the conversations and ask clarifying questions. All conversations were transcribed by the researchers in-situ which also allowed preliminary mapping and sense making of the data. Drawing on these evolving narratives we began to identify a 'constellation of orientating concepts' (Smyth, Hattam et al, 2004, p.74), acknowledging that these kinds of constructs are always approximate and subject to reformulation (Foley, 2002, p.477).

Each of the narrative portraits involved two types of commentary - descriptive and reflective. Again, as researchers we appreciate that our subjectivity is always present in our research; 'it is a garment that cannot be removed' (Peshkin, 1988, p.21). Like turning a plank of wood into a complex piece of furniture, we crafted the slabs of transcribed text (dialogue) into narrative portraits, trimming and smoothing the edges to reveal the emergent nature and essence of what is being experienced and understood by these young people in context. These portraits not only provided a rich source of textual meanings but a space in which young people had an opportunity to act and speak (Lather, 1991, p.137). Bessant (2007) reminds us that cultivating an ethnographic sensibility is crucial if we are to gain insider understandings of contemporary social problems. Ethnographic interviews with young people allow rich accounts of their lives and experiences to emerge in the context of their cultures, communities, aspirations and expectations of work and life. Although in one of the background studies, we interviewed teachers, program managers and significant adults in students' lives, we attached the greatest weight to young peoples' narratives. In the following discussion we shall draw on seven of these narratives to help us illustrate and explain something about the complex interface between the life of schools, family and world of work. 


\section{Pushed out, shut out: Wasted lives in an era of insecurity}

By whatever metric, whether academic achievement, participation, retention, graduation, behaviour, suspension, employment or mental health and wellbeing, unacceptably large numbers of young people at the beginning of 21st century are not benefiting from the rewards of education and/or work, especially those living in poverty and communities of disadvantage (Saunders, 2011; Vinson, 2007; Greig, Lewins and White, 2003; Raffo et al, 2009). Despite the rhetoric around social inclusion and policies of Learning or Earning (Council of Australian Governments (COAG), 2009), far too many young people are not only being pushed out of education due to economic and cultural processes of advantaging and disadvantaging (Teese and Polesel, 2003; Connell, 1993) but shut out of the labour market as a consequence of profound shifts in the global economy (Harvey, 2010; Aronowitz and DiFazio, 2010). In Australia, official statistics show that between 30-40 per cent of young people are making the active choice not to complete secondary education. In disadvantaged communities, 55 per cent of students fail to complete 12 years of schooling. In rural and regional Australia the figures become progressively worse (Australian Productivity Commission, 2010; WA Department of Education, 2010). As a consequence, 15.9 per cent (up nearly $3 \%$ on 2008 figures) of 17 year olds are not fully engaged in full-time work or part-time education. These young people are marginalised to part-time work $(6.4 \%)$, unemployment $(4.7 \%)$ or withdrawal from the labour market $(4.8 \%)$. This marginalisation is even more pronounced among older teenagers with more than 25 per cent of those aged 18 not fully engaged and for 18-19 year olds the figure is 29.1 per cent (Foundation for Young Australians, 2010, p.6).

Whilst these figures are useful at one level, they do not reveal the full extent of what Bauman (2011, p.9) describes as 'the explosive compound of growing social inequality' and the rising volume of human suffering relegated to the status of 'collaterality'. As Bauman (2004) so vividly puts it, these 'wasted lives' represent a significant and potentially 'disastrous' problem for humanity because when students fail to complete schooling then as a society we are all worse off. Tony Vinson's (2007) report on the spatial distribution of disadvantage in Australia demonstrates a disturbing link between 'such factors as early school leaving, low job skills, longterm unemployment, court convictions and eventual imprisonment' (p.xii). He describes an 'enduring story of the disadvantaging consequences of limited education and associated lack of information retrieval and exchange skills, deficient labour market credentials, poor health and disabilities, low individual and family income and engagement in crime' (p.96). Adding to this concern, the International Labour Organization (ILO) recently "warned of a "scarred" generation of young workers facing a dangerous mix of high unemployment, increased inactivity and precarious work' (10 October, 2011).

Against this backdrop, the question becomes then, why do so many young people choose to disengage from schooling? One explanation focuses on the alienat- 
ing nature of 'doing' high school, in particular the difficulties created by large class sizes, rigid timetables, hierarchical structures, didactic pedagogies, punitive behaviour management regimes, poor facilities, measurement and testing, standardisation, lack of creativity, labelling, streaming, irrelevant curriculum, vocationalisation, and poor relations with teachers; and this is to name a few (Pope, 2001; Smyth, Angus, Down and McInerney, 2008). A second explanation tends to focus on individual and pathologising explanations such as adolescent psychology, peer relationships, poor attitudes, race, laziness, and lack of motivation, low ability, low IQ, dysfunctional families, disruptive behaviour, incompetent teachers, and poor school leadership (Valencia, 2010). In response to these perceived deficits, governments and education systems, with the few exceptions of Scandinavian countries, have largely pursued policies that are 'muscular, managerialist, punitive, hortative and largely non-inclusive of the people who are most affected, namely marginalised young people' (Smyth, Down and McInerney, 2010, p.1).

As critical educational researchers, we are interested in conducting research that supports and advocates 'for those whose voices are not always clearly heard' (Shields, 2012, p.10). We want to bring some perspective to the issues of marginalisation, alienation and disengagement by listening to how young people themselves make sense of school life. To begin, we shall draw on Gary's experience of what high school was like for him in order to help us better understand 'how schools do policy' and with what effects (Ball, Maguire and Braun, 2012). In Gary's case, the catalyst for him leaving school was the enactment of the Western Australian Behaviour Management in Schools policy (2001, 2008). Whilst official policy discourses pledge to provide 'a high quality public school system ... to make every student a successful student' (WADET Plan for Public Schools 2008-2011, p.4) and 'provide a safe, welcoming and caring space for all students' [italics added] (WADET, 2001, 2008, p.1), the reality for students like Gary is very different because he is framed as a problem student.

Gary is 16 years of age, tall, beginning to grow sideburns and starting to shave. He likes to skate board and hang out with friends at school. When we interviewed Gary he indicated that he was struggling with the newly enforced uniform rules. 'It happened 3 weeks ago in science. I refused to take my jumper off. The teacher kept telling me to take it off because it wasn't uniform and I had a cold at the time so I didn't want to take it off. So I got kicked out of class and given a detention notice'.

Two of Gary's classmates who had nominated to be participants for this research, could not attend the interview, as they had already lost their 'good standing' for being 'out of uniform' due to their persistence in wearing denim clothing. Gary was fed up with the emphasis and enforcement of school uniform. Furthermore, he had gone out of his way to make sure that he was dressed in a uniform of his own; entirely black, with the occasional commercial advertising logo rather than the compulsory school one because, 'if they did not make such a big deal about it, then I would probably wear it ... but I choose not to, just to piss them off!" 
Gary also reveals some of his frustration at being controlled in class because 'we get sent out for just asking questions. The teacher expects us to behave yet sits us next to people that we don't like. If I go and sit next to my friend, she yells at me, yet she places people together who stuff up'. (Gary, May 2007)

The introduction of a rigid Uniform policy is linked to what is known as the Good Standing policy in the school. A section of Anchorage High's Good Standing policy is described below to accentuate how current punitive control mechanisms presently considered 'normal' can all too easily evolve into forms of control. Gary's name appears in this pro forma letter:

Students who lose their 'Good Standing' are required to complete a report card. This card will require a signature from every teacher each day for a week as well as having a parent signature each evening. Should [Gary] fail to complete this within the week, additional time will be added to [Gary's] loss of 'Good Standing'. (p.5)

The Minister for Education and Training of Western Australia (2007), believed that 'traditional styles of uniform will play an important part in keeping up the strong reputation of public schools and ensuring parents continue to send their children to public schools' (DET, 2007, p.1). In this context, Gary's refusal to obey the uniform code was considered to be a breach of the school's 'code of conduct' thus jeopardising his 'Good Standing'. Ultimately, the Principal had authority to apply sanctions prescribed in the School Education Regulations 2000 (pp.22-3) if students failed to comply with uniform codes. This meant that Gary was unable to attend school excursions, end of term functions or reward days as punishment and yet he had expressed how significant these events can be in his life; 'I want to go on the river cruise, but it will mean that I have to buy a uniform. That is the only thing that I have lost my good standing for is uniform. But for 4th term, I am going to buy the uniform so I can go. That is the only time I will wear uniform'.

This event marks the end of ten years of schooling with his peers, however, by the time we came to interview Gary the second time around, a few weeks later, he had been in so much trouble with Student Services that he had been placed on an Individual Education Plan (IEP) in order to better manage his non-compliance. By the third visit, two months later and only half way through the school year, Gary had left.

Ball et al (2012) argue that 'behaviour is constituted within a 'field of interpretations' (p.116). It is 'always contested and changing (unstable)' and 'not quite finished' (p.119). Whilst the Department of Education (WADET, 2010) endorsed uniform codes as 'effective in addressing student behaviour' (p.62), the reality was that it served to push out 'troublesome' students like Gary. In 2010, over twelve thousand students, nearly 5 per cent of total numbers in public schools in Western Australia, were suspended (p.62). Sixty recommendations were made to the Department to exclude students from school altogether and fifty-four of these were accepted. Not all of these exclusions are for serious or violent crimes and can be for 
'persistent breaches of the schools code of conduct' (p.62), which can mean anything from answering a teacher back, lateness to class, or refusing to comply with rigid school uniform codes.

It is not our intent to portray Gary as a 'typical' student in order to highlight the number of students who leave school for not wearing a school uniform, but rather to show how such altercations and signs of resistance can readily escalate to the point where students are suspended or excluded, or as Smyth and Hattam et al (2004) explain it, 'dropping out, drifting off, and being excluded'. As Connell et al (1982, p.88) argue, this resistance by students is in relation to the school and is often generated by the interaction with the authority structure. Eventually students leave school as they give up the struggle. This is what happened to Gary, but not before he exercised some resistance; 'if only they did not make such a big deal I would probably be able to do what they want, but they wear me down, make such a big deal that it is easier if I just don't do what they want ... at least then I can be a winner somehow'.

Many of the students that we interviewed for this research were caught up in a similar loop of contestation or resistance and did not feel they were treated fairly by the school. Typically, they did not feel a sense of belonging or connectedness to the institution of schooling. Wexler (1992) explains that school life 'centres around the daily project of establishing a social identity' (p.128). Frictions develop when the focus on behaviour management frames students like Gary 'as problem students' (Hattam and Prosser 2008, p.96). The total 'Good Standing' process after report card stage is intended to involve meetings with parents, case conferences, support staff, district office representatives and other agencies. This entire negotiation process is rarely experienced by students like Gary as they have already been pushed out at the initial report card stage.

Listening to students' stories allows us to gain a much greater appreciation of the extent to which behaviour policies and practices are informed by 'pathologising' and 'homogenising' discourses (Valencia, 2010). For instance, the Department's decision to employ extra psychologists, chaplains and school volunteers to be part of a 'specialist behaviour' team (WADET, 2010, p.64) as well as an additional \$2.5 million dollars per year to hire principal consultants to 'train' teachers in the technical skills 'to reduce unproductive behaviour in classrooms and increase student engagement' (p.61), ignores how institutional, pedagogical, cultural and structural arrangements in schools and society contribute to the problem of alienation and disengagement. Questions of pedagogy, curriculum and assessment are easily dismissed as the focus of non-compliance to rules and regulations shifts to the individual (Araujo, 2005, p.247) thus resulting in a range of therapeutic interventions to 'fix' students (Ecclestone and Hayes, 2009). Wexler (1992) makes the point that, in fact, 'the crisis of education is a crisis in the school itself, and that crisis is a crisis of society' (p.155). In other words, that what happens in schools and local neighbour- 
hoods (and those who inhabit them) cannot be divorced from the operation of social, economic and political power in the wider society.

Students like Gary often became bored with the curriculum presented to them, losing interest as their needs, desires and aspirations are ignored. They become 'silent witnesses' to a gradual process of marginalisation and disenfranchisement from schooling (Smyth and McInerney, 2012a). If left unexamined, deficit approaches to policy at the school level function to obscure institutional structures and processes at work whilst ignoring 'patterns of laceration and rupture' or 'school wounds' experienced by students themselves (Olsen, 2009, p.4). Olsen's (2009) notion of school wounds resonates strongly with the key messages we heard from students' stories in our own research. Students believe they aren't 'smart', they don't have what it takes to succeed in school (and by implication, life), their ideas lack value or validity, all their efforts, no matter how hard they try, are below standard and that they are 'flawed people'. They also feel ashamed of themselves and their efforts and they develop 'learned helplessness'. Students show less pleasure, less courage in learning and have lowered ambition, less self-discipline, and diminished persistence in the face of obstacles (Olsen, 2009, p.26). It is hardly surprising therefore to hear that significant numbers of students are disconnecting from school or lost in the system. Practices involving 'toxic labelling' (Hudak, 2001, p.14) and 'disparaging epithets' (Brantlinger, 2003, p.11) take hold in unthinking and commonsense ways. Students soon find themselves labelled as 'at risk', 'non-academic', 'disengaged', 'behavioural problems', and 'troublemakers'. In response, a range of interventions and policing regimes are adopted to 'fix' the perceived problem such as: the 'Student Information System' (SIS); 'Keeping Kids in Schools' SMS, 'messaging in Watcheyes function'; FastTrack whereby young people are streamed into what Kincheloe (1999) describes as the 'Sixth circle of educational hell - the low achiever' (p.258); and 'Positive Parenting' programmes for families.

Students involved in these types of intervention programmes are typically classified as 'not engaged' (7\% of total student population in Western Australia) because they are 'in transition, refusing, whereabouts unknown, deceased or have left the state' (WADE, 2011, p.66) and become classified as one of the '1,749 non-participating students' (Curriculum Council WA, 2011, p.15). David was one of these students. He had left school in Year 8 at only 13 years of age. He was unhappy and constantly bullied at school and nobody seemed to care. When teachers and administrators become preoccupied with issues such as conforming to school uniform codes (and a myriad of other administrative tasks), then there is only so much time and energy that they have left to help those in a real crisis. David's story reveals a good deal about what happens when students' lives are dismissed, ignored or glossed over in the intense busyness of 'doing' school:

I was not connecting with anything at school and it was not working for me. I was overwhelmed and not happy so I left in $\mathrm{Yr} 8$ and my memory about it is patchy since then. 
Mum enrolled me in the other high school but the same thing happened (bullying). I didn't feel like I was learning anything because by the time I went there I was really out of touch with school. I had been away for so long and felt like an outcast. I was persecuted for that. (David, April 2012)

When student behaviour is managed and measured by compliance to a school code of conduct that emphasises conformity, punctuality, quietness, following teachers' orders and wearing the correct attire then it is easy for students like David to be forgotten or Gary to be labelled as having the wrong attitude. Students' themselves help us to put a different inflection on how schools really work (or not) and in whose interests. For Gary and David, there is an overwhelming feeling of disempowerment disenchantment and disaffection which ultimately causes them to leave school altogether. This has major consequences for the individual and society 'especially where poverty, insecurity and hybrid forms of existence between employment and unemployment are central to the context from which young people construct and make choices' (Wyn, 2007, p.38).

Whilst official pronouncements recommended that 95 per cent of 19 year-olds should have completed Year 12 or an initial post-school qualification or be participating in formally recognised education or training by the year 2001 (Finn Report, 1991), the lived reality is vastly different for those students struggling to find a reason to 'hang in' (other than it's mandatory until 17 years of age) at school. Disturbingly, young people are not only being pushed out of school but shut out of an increasingly hostile, fragile and insecure labour market in which secure jobs are rapidly disappearing (Brown and Hesketh, 2004; Brown, Lauder and Ashton, 2011; Beck, 2000; Sennett, 1999). Historically, one of the main logics of schooling is its function to prepare students for the world of work and 'getting a job' (Down, 2009). In neoliberal discourses, therefore, the emphasis has been on refashioning schools around a narrowly conceived and instrumental vocationalisation of the curriculum so that students are 'job ready'. In Western Australia, as other western economies, we have witnessed a proliferation of Vocational Education and Training (VET) in Schools programmes to the point where nearly half of the Australian student cohort enrolled in a senior secondary school graduation certificate are now enrolled in some form of vocational education and training (Polesel and Keating, 2011, p.369).

Whilst the vocational education and training turn in schools appears on the surface to address the problem of student (dis)engagement by assuming that the nonacademic kids can 'work with their hands, not their minds' (Kincheloe, 1999, p.139), it is not without problems. For example, Polesel and Keating, (2011, p.369) claim that retention rates of VET in Schools in Australia have stagnated by 75 per cent since 1992. Furthermore, they acknowledge that it does not prepare young people for any particular occupation and the skills and knowledge gained are of very low quality (p.374). Adding to this concern, Buchanan et al (2009) believe that: 
...the narrow approach to competence in VET limits the ability for the sector to provide a quality general education which is transferable across a range of industries. In particular, it limits students' access to forms of knowledge that facilitate autonomous reasoning - at work and beyond (p.3).

Compounding the situation, VET courses in Australia have very low completion rates, as much as 30 per cent (Bednarz, 2012, p.13). These figures are further complicated when one considers that in some schools, such as the one Gary attended, up to 40 per cent of students had left school before the end of year 12 (WADE, 2010). Suffice to say that the promise of vocational education and training has not always lived up to the claim of helping young people to find secure and rewarding jobs. Of greater concern, is the failure of VET to address the conditions it purports to eliminate - poverty, unemployment and economic inequality (Kantor and Tyack, 1982). Young people are facing an uncertain and precarious future dominated by both a shrinking labour market for professional and technical labour and growth in casual, part-time, low skilled and poorly paid service industry jobs (Cuban, 2004) as reflected in Richard's story:

Like Gary and David, Richard attended a large secondary school in the 'Bountiful Bay' area. Richard elected to do a Vocational Education and Training in Schools course. 'I want to become a mechanical fitter. Last year in our first work experience block I went out to the power station and worked with them and I enjoyed that sort of work. I tried this trade and liked it and now am ringing up companies. I would like to get an apprenticeship in this field. Staying on in the academic stream is not going to add anything to what I want to do and my TAFE certificates should help me get a job. I've been a school leader. I was head boy at Kwella College, voted by my peers. They trust me. The TAFE course has been very good. Gaining the certificates means that I'm more qualified than the other guys. When it comes to securing an apprenticeship it is all about timing and taking advantage of opportunities as they arise'. (Richard, August 2011)

In our second interview with Richard, seven months later, he had left school and was struggling to find a job. He was feeling angry and upset about this situation, something we observed in our field notes.

Richard is disillusioned and angry about the world and struggling to find permanent work or an apprenticeship.After being the head boy of his school last year, his enthusiasm for life after school had been severed. He had completed VET technical training, work experience and was well prepared with interview techniques and a polished CV. He had a continuing casual job with 'Rick White's Electronics', but finding it difficult to make any definite or future plans in regards to permanent work, social, family and financial situations. He felt let down because each time he finally reached interview stage, no one was really interested and he sensed no one was listening. He said 'the guys in t-shirts and thongs get the job'. He was also frustrated by the lack of acknowledgment to his many job applications and was rapidly losing enthusiasm to try again. (Field notes, March 2012) 
Richard is one of a growing number of young people who feel betrayed by the 'broken promises of education, jobs and rewards' (Brown, Lauder and Ashton, 2011; Sidorkin, 2004). Richard's story is not uncommon. As mentioned earlier, Tony Vinson's report, Dropping off the edge (2007), found that despite the nation's strong economic growth in recent decades, some communities are trapped in a spiral of low school attainment, high unemployment, poor health, high imprisonment rates and child abuse.

\section{Speaking back to power and authority}

The question becomes then, how do we create and more widely sustain spaces and places for students like Gary, David and Richard to speak back? What are the economic, cultural and pedagogical settings required to assist them to lead productive and economically rewarding lives? When young people are given the space to speak back to power and authority then reengagement in learning and work is more likely. Based on our own research, this involves deep listening to the aspirations, desires, dreams and sense-making of young people themselves (Delpit, 1988). We begin this process by mapping some of the counter narrative stories that can make a difference in the lives of young people based on our research interviews, reflections and commentary. It should not be surprising to find that the dominant themes emerging from these narratives are based on the importance of reasserting the primacy of the relational dimensions of teaching and learning as the cornerstone of engaged pedagogy (Smyth, Down and McInerney, 2010). For young people this involves a sense of belonging and community in which they are treated with respect, trust and care as young adults. Under these conditions young people are encouraged to develop their capabilities and interests by doing socially worthwhile community based projects that are challenging, rigorous and fun. As Stengers (2002) explains it, these are places of hope in which young people are encouraged to 'think' and 'feel' about the things that really matter to them (p.257).

'They handle things differently here'

Sharon had revealed an all too familiar story of rejection, alienation and exclusion that constitute many young people's experience of mainstream schooling. Disaffection with petty rules, large class sizes and rampant bullying had all contributed to her decision to leave school and enrol in the Connextions Education program. This is when the situation changed and Sharon's experience of learning improved because as she describes it, 'they handle things differently in this alternative program'. This was because there was more emphasis on applied learning, teachers provided more individual support in class, students had opportunities to express their ideas and pursue subjects of special interest to them and conflicts were dealt with in a more dialogic and less confrontational manner. (Sharon, narrative portrait, June 2010)

'Here I have more freedom to do things for myself'

Hayley expresses the major differences she has experienced between school and an alternative programme. 'Here you don't have to wear a uniform. When you came here you 
feel more relaxed and everyone is very welcoming. School didn't work out for me. I was bullied and the work was just getting too much. I finished year 10 and then came up here. Since joining this program I like to think that I'm more organised. I get all my stuff together and that makes me smarter and makes me want to do more. At school if you don't do it you get punished. I got detention for being 2 minutes late and that's just crap. Here I've got freedom to do things myself. Instead of teachers giving you a project they let you pick your own'. (Hayley, March 2010)

'Sometimes I've been able to look back and say, 'Well I've changed'.

There are tragic strands to Dylan's life but amidst the carnage of fractured family relationships, falling out of school, time in juvenile detention, coping with the death of his father, and bouts of depression, there are signs that his life is changing for the better. Since joining the CCAL program program Dylan has gained confidence and has a much clearer idea of what he wants out of education. He has an opportunity to work on projects that interest him and is treated like an adult by a team of supportive teachers. (Dylan, narrative portrait, March 2010)

'I didn't want to be left behind and have no money. I wanted a good job'

Jackie told us that what she didn't like about school was being judged, the uniforms and getting suspended. 'It makes me angry and upset when they say I am not going to make anything of myself. They don't have a right to say that. When I first started school Mum was going to jail so I was hanging out with the wrong people. Life at home was not good and there was the usual fighting. Jay (case worker), my couple of friends and a couple of teachers who are nice have helped me get back on track. I now see that you need an education to get on in life. I am not hanging out 'with the crowd' anymore. I am still the same person but I have quietened down a bit and don't go out and get in trouble with the cops anymore.

Jackie also told us what helped motivate that change: 'I didn't want to be left behind and have no money. I wanted a good job. I didn't want to be a druggie loser on the dole'. (Jackie, August 2011 and April 2012)

Common to each of these narratives is the manner in which young people have been able to forge their own sense of identity and agency as they tackle a range of social, economic and cultural obstacles to completing their education and 'getting a job'. For some, it involved blocking out painful experiences from fractured family life and relationships. Without the security of a safety net, these students understood that if they did not take some action then they were likely to end up at the bottom of the educational and employment ladder. These harsh realities provided a sharp reminder of the competitive dog-eat-dog world in which they live. When students' lives are so fraught with pain and dysfunction we should hardly expect that they would be the kind of students who are likely to comply and remain silent in the face of injustice and hardship. A far more sophisticated and nuanced level of thinking and action will be required to truly re-enchant these young people with learning. These narratives are a key element in understanding the complexities of youth identities in chaotic and uncertain times and 'especially relevant to patterns of employment and un- 
employment in the service sector of urban economies' (Wyn, 2007, p.38). Based on these narratives, we can begin to identify some key guiding principles to assist us in the task of reclaiming a democratic politics of schooling and work. By way of summary we have listed five key organising elements to help us scaffold the foundations of a new geography of socially just schooling.

1. Relationships: Genuine student-teacher relationships are the centrepiece of all aspects of teaching and learning. Relational schools are founded on principles of respect, trust and care, and show a willingness to take students seriously and acknowledge their voices in all aspects of schooling. By actively listening to students the focus shifts from 'doing to' to 'working with' students on things that matter to them. In the process, schools demonstrate a preparedness to interrupt deficit views of students, their families and communities and recognise all students as having capabilities and aspirations to succeed in education, life, and careers (Smyth, Down and McInerney, 2010, p.201). Freire (1998) captures it well when he states that 'we must dare, in the full sense of the word, to speak of love' as the cornerstone of truly dialogic encounters between teacher and student (p.3).

2. Organisation: Rather than allowing organisational structures and timetables to drive the curriculum, there is an intentional effort to create a school culture where 'students come first'. The relational school knows each student well and is willing to put their needs and interests above all else (Smyth, Down and McInerney, 2010, p.202; Robinson, 2011). Such schools are more flexible, responsive and personalised around the needs and interests of all students. They understand that it takes time, energy, commitment, and persistence over time to succeed (Vinson 2007, p.101). To this end, there is a deliberate intent to foster a spirit of reciprocity, reflexivity and coexistence with others to achieve common goals for the benefit of all (Burbules and Torres, 2000, p.22).

3. Community: Community oriented schooling acknowledges that young people's lives are shaped in local neighbourhoods and communities (Smyth, Angus, Down and McInerney, 2009). There is, then, a focus on schools as a significant resource to promote civic engagement and build social capital in ways that open up new possibilities for parental and community participation. Furthermore, schools acknowledge and value the 'funds of knowledge' available in local communities (Gonzalez, Moll and Amanti, 2005). Reframing school-community relations in these ways affords an opportunity to engage in community life as 'a source of fun, avoidance of boredom, vehicle for self-expression, self-protection and self-confirmation' (p.91). Thus schools and communities can work together on 'economic, social and political changes inside and outside schools' (Cuban, 2003, p.60).

4. Work: Schools are absolutely pivotal to preparing young people with the capabilities to succeed in the world of work and life. Young people want an education that is relevant, challenging and capable of integrating academic and manual learning 
around socially worthwhile projects in the real world. As Ball, Maguire and Macrae (2000) rightly argue, there needs to be an 'unblurring' of the links between education and the training needs of the labour market (p.7). Only then can we avoid the diminishing and demeaning consequences of 'job training' in order to pursue a richer and more democratic approach to the field of work education.

5. Pedagogy: Students deserve a pedagogy that begins with their own experiences in order to produce a curriculum that is relevant, rigorous and meaningful. Schools that create these kinds of cultural settings are innovative, flexible, success orientated and resourceful yet have high expectations and provide the space and resources to negotiate a curriculum that is important. This is a pedagogy in which students are no longer 'positioned as passive consumers' but 'active creators of knowledge in their own right' (Smyth, Angus, Down and McInerney, 2009, p.38). Learning takes place in real world contexts with accomplishments demonstrated through authentic forms of assessment and exhibition of students' work.

\section{Conclusion}

When young people are positioned as key informants in research we gain a much richer appreciation of the fundamental importance of social relationships and identity formation in their lives. Our conversations with young people across multiple sites, reveals that many of them are disaffected with mainstream schooling because their needs are not being met. Essentially, these young people are searching for meaningful connections with people who care deeply about them and their futures. In this context, the values of respect and relational trust are absolutely essential to establishing a sense of identity and belonging. Only then is it possible to create the kinds of pedagogical conditions in which teaching and learning can occur.

Juxtaposing these pedagogical considerations is the chaotic and unpredictable nature of the global economy and the profound impact on young people in terms of finding secure, rewarding and well-paid work. Gone are the days of relative certainty and security of employment where one made a relatively smooth transition to adulthood and the world of work (Dwyer and Wyn, 1998, pp.296-7). In this article young people themselves have effectively 'forced a space' (MacLure, 2003, p.165) to generate 'wonder, meaning, understanding and knowledge' (Somerville, 2008, p.217) with which to speak back to the unjust geographies of schooling and work.

\section{Acknowledgements}

We wish to acknowledge the financial support and cooperation of the Australian Research Council (ARC) and Industry Partners (IP) who have funded the research projects informing this article. In particular, the ARC Linkage Grant Scheme projects School and Community Linkages for Enhanced School Retention in Regional/Rural Western Australia 2005-2007 (Smyth and Down) with the Western Australian Department of Education; Getting a Job: Vocationalism, Identity Formation and Schooling in Communities at Disadvantage 2010- 
2013 (Down and Smyth) with the Western Australian Department of Education, Kwinana Industries Council, Bridging the Gap, Town of Kwinana, City of Rockingham, Challenger Institute of Technology, Seton Catholic College, Tranby College and South West Corridor Development Foundation; and Re-Engaging Disadvantaged Young People with Learning (Smyth and McDonald with Foley) with the Department of Education and Early Childhood Development (Grampians Region). We acknowledge the contribution of Dr Janean Robinson's doctoral thesis, Dr Peter McInerney, Senior Research Associate and Sol Smyth. We extend our appreciation to Murdoch University and the University of Ballarat for providing a supportive environment in which to write and formulate our ideas. We obtained university and institutional ethics approval to conduct this research including the use of pseudonyms to protect the confidentiality of participants.

\section{References}

Araujo, M. (2005). Disruptive or disrupted? A qualitative study on the construction of indiscipline. International Journal of Inclusive Education, 9(3), 241-269.

Aronowitz, S., and DiFazio, W. (2010). The jobless future. Minneapolis: University of Minnesota Press.

Australian Productivity Commission (2010). Report of government services 2010. Retrieved on 9 May 2010 from: http://www.pc.gov.au.gsp/reports/rogs/2010.

Ball, S. Maguire, M. and Macrae, S. (2000) Choice, pathways and transitions post-16: New youth, new economies in the global city. London: RoutledgeFalmer. London.

Ball, S. Maguire, M., and Braun, A. (2012). How schools do policy: Policy enactments in secondary schools: London: Routledge.

Bauman, Z. (2004). Wasted lives: Modernity and its outcasts. Cambridge: Polity Press.

Bauman, Z. (2011). Collateral damage: Social inequalities in a global age. Cambridge: Polity Press.

Beck, U. (2000). The brave new world of work. New York: Polity Press.

Bednarz, A. (2012). Lifting the lid on completion rates in the VET sector: How they are defined and derived, NCVER, Adelaide, retrieved 16 February 2012 from: http://www.ncver.edu.au/ publications/2467.html

Bessant, J. (2007). The value of ethnographic research: University students and financial hardship. Children Australia, 32(4), 25-34.

Brantlinger, E. (2003). Dividing practices: How the middle class negotiates and rationalizes school advantage. New York: RoutledgeFalmer.

Brown, P., and Hesketh, A. (2004). The mismanagement of talent: Employability and jobs in the knowledge economy. Oxford: Oxford University Press.

Brown, P., Lauder, H., and Ashton, D. (2011). The global auction: The broken promises of education, jobs and incomes. Oxford: Oxford University Press.

Buchanan, J., Serena, Y., Marginson, S., and I. Wheelahan (2009). Education, work and economic renewal. An issues paper prepared for the Australian Education Union. Retrieved 17 February 2012 from: http://www/aeufederal.org.au/Publications/2009/JBuchananreport2009.pdf.

Burbules, N., and Torres, C. (2000). Globalization and education: An introduction. In N. Burbules and C. Torres (Eds.), Globalization and education: Critical perspectives (pp.1-26). New York: London: Routledge.

Burgess, R. (1988). Conversations with a purpose: The ethnographic interview in educational research. In R. Burgess (Ed.), Studies in Qualitative Methodology Volume 1 (pp.137-155): JAI Press.

Clandinin, J., and Connelly, M. (1994). Personal experience methods. In N. Denzin and Y. Lincoln (Eds.), Handbook of qualitative research (pp.413-427). Thousand Oaks: Sage Publications.

Connell, R.W. (1993). Schools and social justice. Toronto: OurSchools/Our Selves Education Foundation.

Connell, R.W., Ashenden, S., Kessler, S. and Dowsett, G. (1982). Making the difference: Schools, families and social division. Sydney: Allen and Unwin. 
Council of Australian Governments (COAG). (2009). Communique 5 February, National partnership on youth attainment and transitions. Council of Australian Governments: Canberra. Retrieved August 10, 2009 from: http://www.coag.gov.au/coag_meeting_outcomes

Cuban, L. (2003). Why is it so hard to get good schools? New York: Teachers College Press.

Cuban, L. (2004). The blackboard and the bottom line: Why schools can't be businesses. Cambridge: Harvard University Press.

Curriculum Council of Western Australia (2011). Annual Report 2010-2011. Retreived 20 May 2012 from: http://www.curriculum.wa.edu.au/internet/Publications/Reports/Annual_Reports

Delpit, L. (1988). The silenced dialogue: Power and pedagogy in educating other people's children. Harvard Educational Review, 58(3), 280-298.

Department of Education and Training (2007). Dress requirements for students in WA public schools. East Perth.

Down, B. (2009). Schooling, productivity and the enterprising self: Beyond market values. Critical Studies in Education, 50(1), 51-64.

Down, B. and Smyth, J. (2010). 'Getting a job': Vocationalism, identity formation and schooling in communities at disadvantage. Australian Research Council (ARC) Linkage Grant (LP110100031). Canberra: Australian Research Council.

Down, B. and Smyth, J. (2012). Getting a job: Vocationalism, identity formation and critical ethnographic inquiry. Journal of Educational Administration and History, 44(3), 203-219.

Dwyer, P. and Wyn, J. (1998). Post-compulsory education policy in Australia and its impact on participant pathways in the 1990's. Journal of Education Policy 13(3), 295-300.

Eccelstone, K. and Hayes, D. (2009). The dangerous rise of therapeutic education. New York: Routledge.

Finn, B. (1991). Australian Education Council Review Committee. Young people's participation in post-compulsory education. Canberra: Australian Government Publishing Service.

Foley, D. (2002). Critical ethnography: The reflexive turn. Qualitative Studies in Education, 15(5), 469-490.

Foundation for Young Australians (2010). How young people are faring 2010. Melbourne: Foundation for Young Australians.

Freire, P. (1998). Teachers as cultural workers: Letters to those who dare teach. Boulder, Colorado: Westview Press.

Giroux, H. (2011). Zombie politics and culture in the age of casino capitalism. New York: Peter Lang.

Gonzalez, N., Moll, L., and Amanti, C., (Eds.). (2005). Funds of knowledge: Theorizing practices in households, communities and classrooms. Mahwah, NJ: Lawrence Erlbaum Associates.

Greig, A., Lewins, F., and White, K. (2003). Inequality in Australia. Cambridge: Cambridge University Press.

Hattam, R., and Prosser, B. (2008). Unsettling deficit views of students and their communities. The Australian Educational Researcher, 35(2), 89-106.

Harvey, D. (2010). The enigma of capital and the crisis of capitalism. New York: Oxford University Press.

Hudak, G. (2001). On what is labelled 'playing': Locating the true in education. In G. Hudak and P. Kihn (Eds.) Labelling: Pedagogy and politics (pp.9-26). London: RoutledgeFalmer.

International Labour Organization (ILO) (10 October, 2011). ILO warns of a generation 'scarred' by a worsening global youth employment crisis. Press release. Retrieved on 9 May 2012 from: http://www.ilo.org/global/about-tje-ilo/press-and-media-centre/news/wcms_165465/langen/index.htm

James, R. (2002). Socioeconomic background and higher education participation: An analysis of school students' aspirations and expectations. Melbourne: Commonwealth Department of Education, Science and Training.

Kantor, H. and Tyack, D. (1982) Introduction: Historical perspectives on vocationalism in American eduction. In H. Kantor and D. Tyack (Eds.), Work, youth and schooling: Historical perspectives in American education (pp.1-13). Stanford: Stanford University Press.

Kincheloe, J. (1999). How do we tell the workers? The socioeconomic foundations of work and vocational education. Boulder: Westview Press.

Lather, P. (1986). Research as praxis. Harvard Educational Review, 56(3), 257-277.

Lather, P. (1991). Feminist research in education: Within/Against. Geelong, Victoria: Deakin University Press.

22 International Journal on School Disaffection 
Lawrence-Lightfoot, S. and Davis, J. (1997). The art and science of portraiture. San Francisco: Jossey-Bass.

MacLure, M. (2003). Discourse in educational and social research. Buckingham and Philadelophia: Open University Press.

Madison (2005). Critical ethnography: Method, ethics, and performance. ThousandOaks, California: Sage Publications.

Nespor, J. (1997). Tangled up in school: Politics, space, bodies, and signs in the educational process. Mahwah, N.J.: L. Erlbaum Associates.

Olsen, K. (2009). Wounded by school: Recapturing the joy in learning and standing up to old school culture. New York: Teachers College Press.

Peshkin, A. (1988). In search of subjectivity-one's own. Educational Researcher, 17(7), 17-21.

Polesel, J., and Keating, J. (2011). School completion targets and the 'equivalence' of VET in the Australian context. Oxford Review of Education, 37(3), 367-382.

Pope, D. (2001). 'Doing school': How we are creating a generation of stressed out, materialistic, and miseducated students. New Haven: Yale University Press.

Raffo, C., A. Dyson, Gunter, H., Hall, D., Jones, L., and Kalambouka, A. (2009). Education and poverty: Mapping the terrain and making the links to educational policy. International Journal of Inclusive Education, 13(4), 341-358.

Robinson, J. (2011). 'Troubling' behaviour management: Listening to student voice. Unpublished doctoral thesis. Rockingham, Western Australia: Murdoch University.

Saunders, P. (2011). Down and out: Poverty and exclusion in Australia. Bristol: The Policy Press.

Sennett, R. (1999). The corrosion of character: The personal consequences of work in the new capitalism. New York: W. Norton Publishers.

Shields, C. (2012). Critical advocacy research: An approach whose time has come. In S. Steinberg and G. Cannella (Eds.), Critical qualitative research reader (pp.2-13). New York: Peter Lang.

Sidorkin, A. (2004). Relations are rational: toward an economic anthropology of schooling. In C. Bingham and A.Sidorkin (Eds.), No education without relation (pp.55-69). New York: Peter Lang.

Smyth, J., Angus, L., Down, B., and Mclnerney, P. (2008). Critically engaged learning: connecting to young lives. New York: Peter Lang.

Smyth, J., Angus, L., Down, B., and Mclnerney, P. (2009). Activist and socially critical school and community renewal: Social justice in exploitative times. Rotterdam: Sense Publishers.

Smyth, J., Down, B., and Mclnerney, P. (2010). Hanging in with kids in tough times: Engagement in contexts of educational disadvantage in the relational school. New York: Peter Lang.

Smyth, J., Hattam, R., Cannon, J., Edwards, J., Wilson, N, and Wurst, S. (2004). 'Dropping out, drifting off, being excluded: Becoming somebody without school. New York: Peter Lang.

Smyth, J., and Mclnerney, P. (2012a). From silent witnesses to active agents: Student voice in reengaging with school. New York: Peter Lang.

Smyth, J., and Mclnerney, P. (2012b, [under review]). Making 'space' for disengaged young people who are put at a disadvantage to re-engage with learning. British Journal of Sociology of Education.

Somerville, M. (2008). Waiting in the chaotic place of unknowing: Articulating postmodern emergence. International Journal of Qualitative Studies in Education, 21(3), 209-220.

Stengers, I. (2002). A 'cosmo-politics' - Risk, Hope, Change. In M. Zournazi (Ed.), Hope: New philosophies for change (pp.244-272). Annandale: Pluto Press.

Teese, R., and Polesel, J. (2003). Undemocratic schooling: Equity and quality in mass secondary education in Australia. Carlton, Victoria: Melbourne University Press.

Valencia, R (2010). Dismantling contemporary deficit thinking: Educational thought and practice. New York: Routledge.

Vinson, T. and Jesuit Social Services and Catholic Social Services Australia (2007). Dropping off the edge: The distribution of disadvantage in Australia. Canberra: Jesuit Social Services/ Catholic Social Services Australia.

Western Australia School Regulation Act (1999). School Education Regulations 2000. Retrieved 10 March 2012 from: www.slp.wa.gov.au

Western Australian Department of Education and Training (2001). Behaviour Management in Schools. Retrieved on 5 August 2007 from: http://policies.det.wa.edu.au/our_policies/.

Western Australian Department of Education and Training (2008). Behaviour Management in Schools Retrieved 30 July 2008 from: http://policies.det.wa.edu.au/our_policies/. 
Western Australian Department of Education and Training (2008). Plan for Public Schools 20082011. Retrieved 24 September 2009 from: http://www.det.wa.edu.au/schoolsandyou/detcms/ navigation/shaping-our-schools/.

Western Australian Department of Education (2010). Annual Report 2009-2010. Retrieved 12 Jan 2012 from: http://det.wa.edu.au/education/annualreport/docs/department\%20of\%20educa tion\%20annual\%20report\%202009-10.pdf

Western Australian Department of Education (2011). Annual Report 2010-2011. Retrieved 12 January 2012 from: http://det.wa.edu.au/education/annualreport/docs/department\%20of\% 20education\%20annual\%20report\%202010-11.pdf

Wexler, P. (1992). Becoming somebody: Toward a social psychology of school. London; Washington: Falmer Press.

Wyn, J. (2007). Learning to become somebody well. The Australian Educational Researcher, $34(3), 35-52$. 